\title{
Characteristics of sound production and associated pharyngeal jaws in the tomtate grunt Haemulon aurolineatum (Cuvier, 1830) in Caribbean reefs
}

\author{
Morgane Millot ${ }^{1}$, Frédéric Bertucci ${ }^{1,2,3}$, David Lecchini ${ }^{2,4}$, Sarah Smeets $^{1}$, \\ Malika René-Trouillefou ${ }^{3,4}$ \& Eric Parmentier ${ }^{1, *}$ \\ ${ }^{1}$ Functional and Evolutionary Morphology Lab, University of Liège, Belgium. \\ ${ }^{2}$ PSL Research University: EPHE-UPVD-CNRS, USR 3278 CRIOBE BP 1013, \\ 98729 Papetoai, Moorea, French Polynesia. \\ ${ }^{3}$ Laboratoire de Biologie des Organismes et Écosystèmes Aquatiques (BOREA), \\ Université des Antilles, MNHN, SU, UA, CNRS, IRD, Campus de Fouillole BP 250, \\ 97157 Pointe-à-Pitre, Guadeloupe. \\ ${ }^{4}$ Laboratoire d'Excellence "CORAIL”, Perpignan, France. \\ "Corresponding author: E.Parmentier@uliege.be
}

\begin{abstract}
The ability to produce sounds for acoustic communication is well known in different grunt species (Haemulidae). However, most of the sounds have not been described and the sound-producing mechanism of very few grunt species has been deeply studied. Additional data is needed to search for synapomorphy in the sonic mechanism. This study describes acoustic features and branchial anatomy in Haemulon aurolineatum. Correlations were found between some acoustic features and standard length, showing the largest specimens produced shorter, lower-pitched grunts of higher intensity. Examinations of acoustic features and branchial anatomy show that $H$. aurolineatum uses the same stridulatory mechanism described previously in H. flavolineatum. The unusual feature of Haemulon species concerns the fourth ceratobranchials. These appear to be part of the lower pharyngeal jaws since they possess firmly attached teeth that face the upper pharyngeal jaws. The stridulation results from the rubbing of both pharyngeal and fourth ceratobranchial teeth. This mechanism is probably common to the 23 Haemulon species, but additional information is needed regarding the mechanism of other Haemulinae species to produce stridulatory sounds. Fourth ceratobranchials could constitute a key element of Haemulinae ability to produce sounds providing an eventual synapomorphic aspect of the mechanism in the family.
\end{abstract}

Keywords. Acoustic communication, pharyngeal jaws, stridulatory mechanism.

Millot M., Bertucci F., Lecchini D., Smeets S., René-Trouillefou M. \& Parmentier E. (2021) Characteristics of sound production and associated pharyngeal jaws in the tomtate grunt Haemulon aurolineatum (Cuvier, 1830) in Caribbean reefs. Belgian Journal of Zoology 151: 43-56. https://doi.org/10.26496/bjz.2021.84 


\section{Introduction}

In teleosts, acoustic signals are used during competitive feeding (AMORIM \& HAWKINS 2005), distress or alarm situations (KNIGHT \& LADICH 2014), territorial interactions (LONGRIE et al. 2013; PICCIULIN et al. 2006), conspecific identification, as well as during courtship and agonistic displays (COLLEYE \& PARMENTIER 2012; PARMENTIER et al. 2010a), mate choice (AMORIM et al. 2015), mate quality assessment (AMORIM et al. 2015) or coordination of gamete release (LOBEL 1992). Descriptions of these sounds are based on various acoustic characteristics, including different temporal features (e.g., number of pulses, period of pulses), dominant frequencies and amplitude. Detailed analyses suggest that many of these sounds could be species-specific (COLLEYE et al. 2011; GERALD 1971; HAWKINS \& RASMUSSEN 1978; MALAVASI et al. 2008). In some taxa, acoustic features can also provide information about the individual, such as the age, sex or size of the sender (COLLEYE et al. 2009; LOBEL \& MANN 1995; MYRBERG et al. 1993; PEDRoso et al. 2013; TellecheA et al. 2010). A relationship between spectral and individual features can be found in all species of teleosts, but the quantitative value of this relationship will depend on the mechanisms of sound production involved (PARMENTIER \& FINE 2016).

The high diversity of mechanisms that fish have developed suggests that morphological characteristics promoting acoustic communication evolved independently in distant phylogenetic taxa (PARMENTIER et al. 2017a; SCHNEIDER 1967). Moreover, morphological mechanisms used to produce sounds in fish could result from independent modification of existing structures with other primary functions. In different taxa, existing anatomical structures, such as teeth, bones and swim-bladders, were likely first used in non-voluntary sound production and then selected for signal production (PARMENTIER et al. 2017a). Therefore, sound mechanisms in fish could be examples of exaptations, which refers to a functional character previously acquired for a particular function being later co-opted for a new use (GOULD \& VRBA 1982).

Haemulidae are commonly known as grunts due to their ability to produce sounds in distress situations (e.g., when handheld or netted) and during competitive feeding. It is not known whether sound production in other social contexts takes place, given that no experiments have been performed. Sounds have been reported, but not fully described, when fish were netted or during manual stimulations in H. macrostomum, H. album, $H$. parrai, $H$. carbonarium, H. melanurum, $H$. plumieri, H. aurolineatum, H. striatum, Anisostremus virginicus, Conodon nobilis, Pomadasys corvinaeformis, Orthopristis chrysopterus (BURKENROAD 1930; CUMMINGS et al. 1966; Fish \& MOWBRAY 1970; MOULTON 1958). More precise descriptions of acoustic features have been given in $H$. flavolineatum (BERTUCCI et al. 2014). In H. plumieri and H. flavolineatum, sound production mechanisms have been experimentally associated with stridulation resulting from the rubbing of pharyngeal teeth at the level of the branchial basket (BERTUCCI et al. 2014). In the French grunt (H. flavolineatum), movements of pharyngeal jaws during sound production appeared to correspond to movements described during food processing (BERTUCCI et al. 2014; WAINWRIGHT 1989a, 1989b), supporting that this stridulatory mechanism could be an exaptation of the feeding mechanism (PARMENTIER et al. 2017a). Sound production and acoustic features related to stridulation of the pharyngeal jaws could be common to the entire family (FISH \& MOWBRAY 1970; MOULTON 1958; TAVOLGA \& WODINSKY 1965). However, additional morphological data on other species are needed to confirm this hypothesis.

The present work aims to describe acoustic features and the sound-producing apparatus of the tomtate grunt, Haemulon aurolineatum Cuvier, 1830. This species is found west of the Atlantic Ocean, between Cape Cod (Massachusetts) and Brazil, including the Caribbean, Gulf of Mexico and Central American coasts (MANOOCH \& BARANS 1982). They occur from shallow water to offshore reefs, and are schooling fish whose adults feed on benthic invertebrates (DARCY 1983). The tomtate grunt is one of the most common deep-water reef species at depths greater than 30 metres in the Eastern Gulf of Mexico, and can reproduce all year round (DARCY 1983). 
MILLOT M. et al., Sound production and associated pharyngeal jaws in the tomtate grunt

\section{Material and methods}

\section{Sound collection}

Nineteen specimens of Haemulon aurolineatum (Standard Length, SL: 48-115 mm ) were caught during daytime at the Anse du Mancenillier, on the east side of Grande-Terre in Guadeloupe (French West Indies), in January 2020.

Specimens were gently handheld and maintained within a submerged landing net. A hydrophone HTI96-Min (sensitivity: $-163.9 \mathrm{~dB}$ re $1 \mathrm{~V} \mu \mathrm{Pa}^{-1}$; flat frequency response range $2 \mathrm{~Hz}-30 \mathrm{kHz}$; High Tech, Inc. Long Beach, ms, USA) was placed in the centre of the net and connected to a TASCAM DR-05 portable audio recorder (sampling frequency: $44.1 \mathrm{kHz}, 16$-bit resolution; TEAC, Wiesbaden, Germany). These recordings were performed at sea $(1.2 \mathrm{~m}$ depth), which provides the advantage of not deforming sounds, as can occur in aquaria (PARMENTIER et al. 2014). Specimens were positioned about $3 \mathrm{~cm}$ from the hydrophone until sounds were obtained. Recordings of each specimen never lasted more than three minutes and were stopped when at least 40 sounds were recorded.

\section{Sound analysis}

A minimum of 30 sounds/specimen was analysed. Sounds were analysed with Avisoft - SASLab Pro 5.2.13 software (Avisoft Bioacoustics, Glienicke, Germany). All recordings were sub-sampled at $11,025 \mathrm{~Hz}$, with a high-pass filter then applied to remove frequencies below $50 \mathrm{~Hz}$, corresponding to the majority of background noise.

Several acoustic features were measured for each sound (grunt) (Figs 1-2): grunt duration (ms), number of pulses in the grunt, pulse period (peak-to-peak interval between two consecutive pulses, ms), dominant frequency $(\mathrm{Hz})$ and the amplitude of the dominant frequency peak (dB SPL, Sound Pressure Level). Because the hydrophone was not calibrated, all the fish were recorded the same day, at the same location with the same tools to allow comparison of data between specimens. As the recording loop was not calibrated, SPLs are not absolute values but allow comparison of the relative intensity between all the recorded fish.

When sounds were produced in series, other acoustic features were measured (Fig. 1): series duration (s), number of sounds per series, grunt intervals (interval between the end of a grunt and the beginning of the next grunt in a series, $\mathrm{ms}$ ) and grunt period (interval between two successive repetitions of the same pattern between two grunts following each other in a series, $\mathrm{ms}$ ).

\section{Morphology}

After recording, seven specimens were euthanised with an overdose of tricaine methanesulfonate (MS222). They were fixed in a 5\% formaldehyde solution and, after two weeks, they were transferred to a $70 \%$ ethanol solution. The 12 remaining specimens were freed.

Specimens were dissected under a binocular microscope (Leica Wild M10, Leica, Solms, Germany) coupled to a camera lucida to observe the branchial basket morphology.

Pharyngeal jaws of the biggest specimen (SL: $115 \mathrm{~mm}$ ) were prepared for a classical surface examination by scanning electron microscopy (SEM). Samples were critical point dried with $\mathrm{CO}_{2}$, directly mounted on glass slides with carbon tape, and sputter-coated with a $20 \mathrm{~nm}$ Ag in a Balzers SCD 030 unit (Oerlikon Balzers Coating, Balzers, Liechtenstein). Samples were then examined in a FEI ESEM Quanta 600 for classical secondary electron (SE) imaging. 


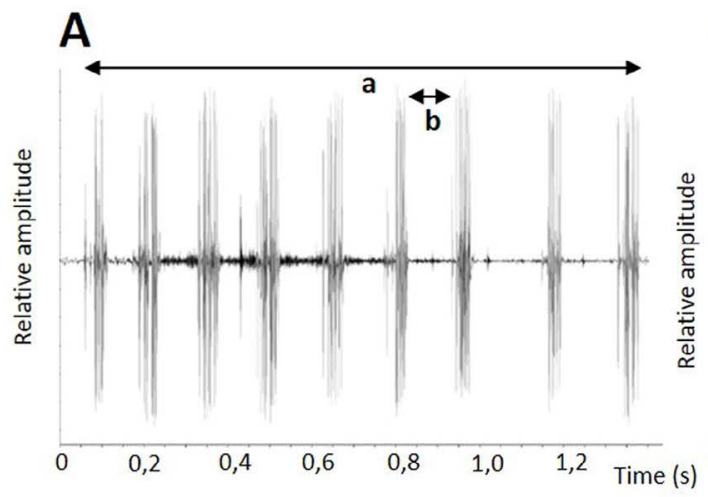

B
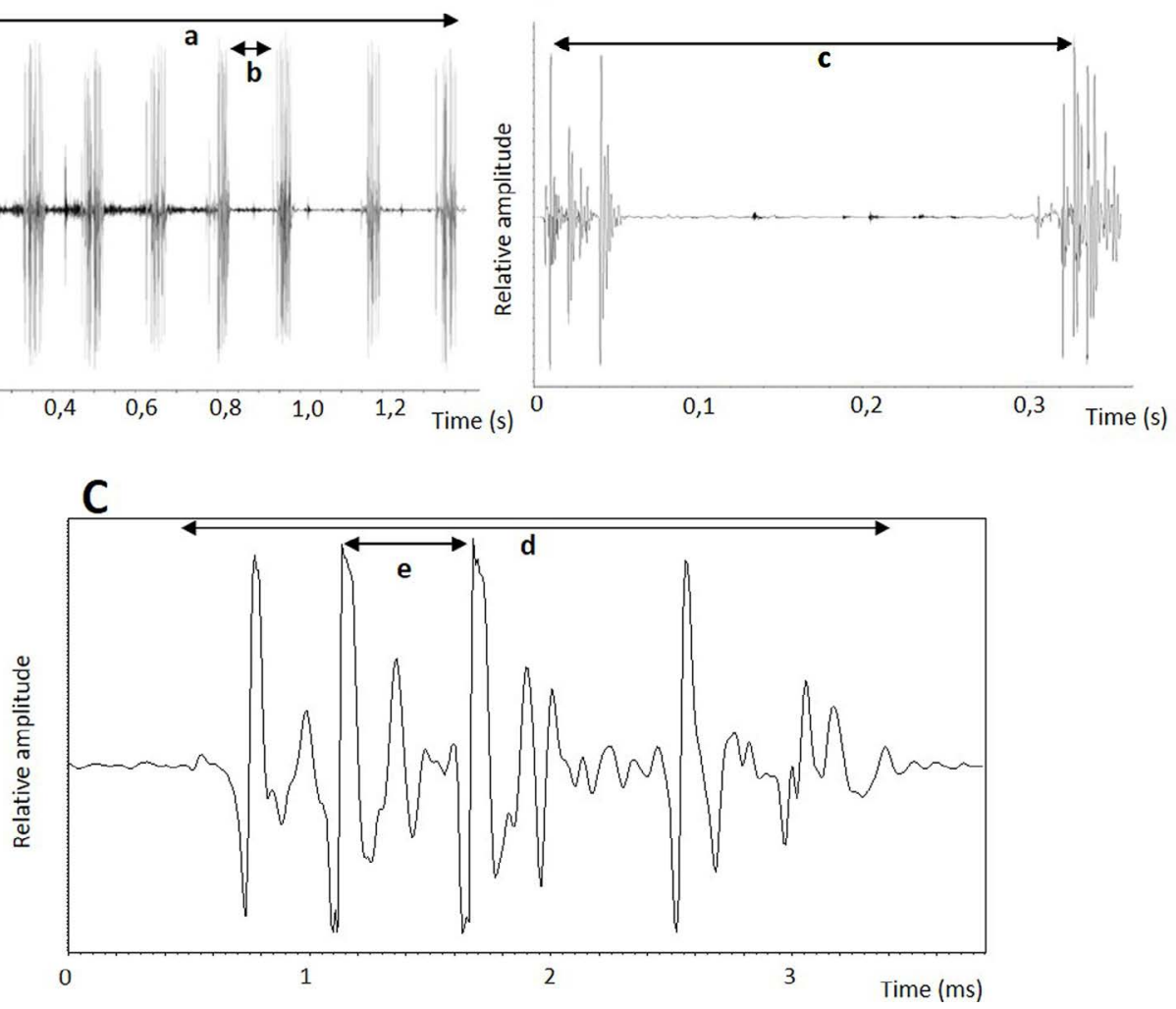

Fig. 1 - Oscillograms (relative amplitude in $\mathrm{dB}$ as a function of time) presenting acoustic features measured for sounds produced by the tomtate grunt, Haemulon aurolineatum. A. Oscillogram of a series of grunts: (a) the series duration (s) and (b) the grunt interval (s). B. Oscillogram of two grunts in a series: (c) the grunt period (s). C. Oscillogram of a grunt: (d) the grunt duration (ms) and (e) the pulse period (s).

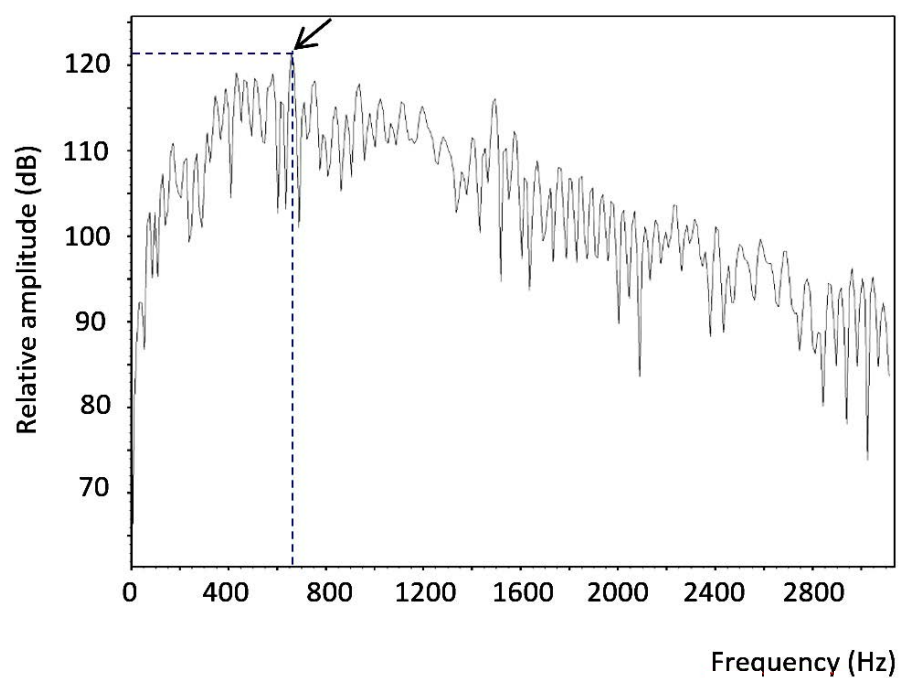

Fig. 2 - Logarithmic power spectrum (relative amplitude as a function of frequency) of a sound produced by Haemulon aurolineatum. Arrow indicates dominant frequency (here $650 \mathrm{~Hz}$ at the relative amplitude of $121 \mathrm{~dB})$. 
MILLOT M. et al., Sound production and associated pharyngeal jaws in the tomtate grunt

\section{Statistical analyses}

Mean and standard deviation were calculated for each acoustic feature of grunts. Analysis concerned 556 grunts from 17 specimens (Table 1). A Shapiro-Wilk test was used to test for normal distribution of acoustic data. A Bartlett test was applied to control homoscedasticity. As the assumptions of normal distribution and homoscedasticity were not met, non-parametric tests were used. A Spearman's correlation matrix was performed between grunt duration (ms), dominant frequency amplitude (dB), mean of pulse periods per grunt (ms), number of pulses per grunt and standard length $(\mathrm{mm})$.

Relationships between amplitude of dominant frequency (dB) and standard length (mm), dominant frequency $(\mathrm{Hz})$ and standard length $(\mathrm{mm})$, and number of pulses per grunt and standard length $(\mathrm{mm})$ were estimated using a linear model (R package "nlme"). Specimens were maintained as a random effect to take into account that each specimen produced a different number of sounds. All statistical analyses were achieved with R studio version 1.1.463 software (RCore Team 2018).

\section{Ethics}

All the experiments were carried out under the approval of the Ethics Committee of the University of Liège (Case 1759).

\section{Results}

\section{Sound production}

Of the 19 specimens collected, one did not produce sounds and recordings of another one could not be analysed because the signal-to-noise ratio was too low. A total of 556 grunts from 17 specimens were analysed. Grunts were isolated or produced in series, lasting between 23.5 and $96.0 \mathrm{~ms}$ (mean $\pm \mathrm{SD}$ : $53.4 \pm 11.7 \mathrm{~ms})$. Their dominant frequency ranged between 303 and $1384 \mathrm{~Hz}(686 \pm 172 \mathrm{~Hz})$, with a relative amplitude between 104 and $135 \mathrm{~dB}(123 \pm 6 \mathrm{~dB})$. Grunts were made of 3 to 12 pulses $(6 \pm 2$ pulses) with a pulse period extending from 1.9 to $37.5 \mathrm{~ms}(9.3 \pm 4.5 \mathrm{~ms})$. Twelve specimens produced grunts in series $\left(\mathrm{n}_{\text {series }}=77\right)$. The four smallest specimens $(48,52,56$ and $57 \mathrm{~mm} \mathrm{SL})$ did not produce any series of grunts. Series lasted from 0.2 to $3.9 \mathrm{~s}(0.7 \pm 0.6 ; \mathrm{n}=150)$ and were composed of 2 to 10 grunts $(3 \pm 2 ; \mathrm{n}=77 ; \mathrm{n}=150)$. Within series, grunt intervals lasted between 10 and $790 \mathrm{~ms}(250 \pm 14 \mathrm{~ms})$ and the grunt period was between 110 and $860 \mathrm{~ms}(310 \pm 140 \mathrm{~ms})$.

There was a positive correlation (Spearman's correlation matrix, $r=0.69 ; \mathrm{p}<0.001 ; \mathrm{n}=556$ ) between the relative amplitude and the standard length, and negative correlations between the dominant frequency $(r=-0.23 ; p<0.001)$ and the number of pulses per grunt $(r=-0.21 ; p<0.001)$ and the standard length. Therefore, longer specimens produced grunts with fewer pulses but with higher amplitude and a lower frequency than smaller specimens. Relationships between these acoustic features were also estimated using linear mixed effect models (Fig. 3).

\section{Morphology}

Upper pharyngeal jaws covered the lower pharyngeal jaws and anterior parts of both ceratobranchials 4 (Fig. 4A). Teeth were present on upper pharyngeal jaws and lower pharyngeal jaws (Fig. 4B-4D).

Teeth of the upper pharyngeal jaw were uniformly distributed on tooth plates. Thin and elongated teeth were found on pharyngobranchials (PBR) 2 and 4, whereas teeth of PBR3 were stout (Fig. 4B). All these teeth possessed a tightening before a sharp tip, bent towards the back of the branchial basket (Fig. 4C). 
TABLE 1

Standard length and acoustic characteristics (mean \pm standard deviation [minimum value - maximum value]) of sounds produced by specimens of Haemulon aurolineatum.

\begin{tabular}{|c|c|c|c|c|c|c|c|c|c|}
\hline Specimen & $\begin{array}{c}\text { Standard } \\
\text { length } \\
(\mathrm{mm})\end{array}$ & $\begin{array}{l}\text { Number } \\
\text { of grunt }\end{array}$ & $\begin{array}{c}\text { Grunt } \\
\text { duration } \\
(\mathrm{ms})\end{array}$ & $\begin{array}{c}\text { Dominant } \\
\text { frequency } \\
(\mathrm{Hz})\end{array}$ & $\begin{array}{c}\text { Relative } \\
\text { amplitude } \\
\text { (dB) }\end{array}$ & $\begin{array}{c}\text { Number } \\
\text { of pulse } \\
\text { per grunt }\end{array}$ & $\begin{array}{l}\text { Number } \\
\text { of series }\end{array}$ & $\begin{array}{c}\text { Series } \\
\text { duration } \\
\text { (s) }\end{array}$ & 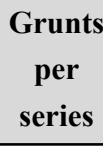 \\
\hline A & 115 & 57 & $\begin{array}{c}50 \pm 9 \\
(40-70)\end{array}$ & $\begin{array}{c}547 \pm 80 \\
(347-954)\end{array}$ & $\begin{array}{c}129 \pm 3 \\
(121-134)\end{array}$ & $\begin{array}{l}5 \pm 1 \\
(3-8)\end{array}$ & 10 & $\begin{array}{c}0.6 \pm 0.5 \\
(0.4-2)\end{array}$ & $\begin{array}{l}2 \pm 1 \\
(2-4)\end{array}$ \\
\hline B & 94 & 52 & $\begin{array}{c}60 \pm 7 \\
(40-70)\end{array}$ & $\begin{array}{c}785 \pm 179 \\
(455-1229)\end{array}$ & $\begin{array}{c}129 \pm 2 \\
(124-129)\end{array}$ & $\begin{array}{l}5 \pm 1 \\
(3-8)\end{array}$ & 7 & $\begin{array}{l}0.9 \pm 0.5 \\
(0.3-1.7)\end{array}$ & $\begin{array}{c}5 \pm 3 \\
(2-10)\end{array}$ \\
\hline $\mathrm{C}$ & 68 & 11 & $\begin{array}{c}50 \pm 8 \\
(40-70)\end{array}$ & $\begin{array}{c}607 \pm 68 \\
(528-767)\end{array}$ & $\begin{array}{c}123 \pm 2 \\
(117-126)\end{array}$ & $\begin{array}{l}6 \pm 1 \\
(4-7)\end{array}$ & 2 & $\begin{array}{c}0.3 \pm 0.01 \\
(0.27- \\
0.29)\end{array}$ & $2 \pm 0$ \\
\hline D & 87 & 49 & $\begin{array}{c}40 \pm 8 \\
(20-60)\end{array}$ & $\begin{array}{l}688 \pm 121 \\
(504-992)\end{array}$ & $\begin{array}{c}131 \pm 3 \\
(123-135)\end{array}$ & $\begin{array}{l}5 \pm 1 \\
(3-8)\end{array}$ & 9 & $\begin{array}{l}0.5 \pm 0.4 \\
(0.2-1.3)\end{array}$ & $\begin{array}{l}4 \pm 3 \\
(2-9)\end{array}$ \\
\hline E & 74 & 37 & $\begin{array}{l}50 \pm 12 \\
(20-80)\end{array}$ & $\begin{array}{l}644 \pm 130 \\
(477-997)\end{array}$ & $\begin{array}{c}118 \pm 5 \\
(110-126)\end{array}$ & $\begin{array}{l}4 \pm 1 \\
(3-8)\end{array}$ & 0 & NA & NA \\
\hline $\mathrm{F}$ & 70 & 47 & $\begin{array}{l}70 \pm 11 \\
(20-80)\end{array}$ & $\begin{array}{c}696 \pm 165 \\
(455-1008)\end{array}$ & $\begin{array}{c}119 \pm 5 \\
(109-128)\end{array}$ & $\begin{array}{l}5 \pm 1 \\
(3-7)\end{array}$ & 6 & $\begin{array}{c}0.4 \pm 0.1 \\
(0.3-06)\end{array}$ & $\begin{array}{l}2 \pm 1 \\
(2-3)\end{array}$ \\
\hline G & 87 & 68 & $\begin{array}{c}50 \pm 9 \\
(40-100)\end{array}$ & $\begin{array}{l}644 \pm 170 \\
(402-963)\end{array}$ & $\begin{array}{c}122 \pm 4 \\
(109-128)\end{array}$ & $\begin{array}{l}6 \pm 1 \\
(3-9)\end{array}$ & 13 & $\begin{array}{l}0.8 \pm 0.6 \\
(0.4-2.7)\end{array}$ & $\begin{array}{l}3 \pm 1 \\
(2-7)\end{array}$ \\
\hline $\mathrm{H}$ & 80 & 49 & $\begin{array}{c}60 \pm 8 \\
(40-70)\end{array}$ & $\begin{array}{l}603 \pm 105 \\
(303-865)\end{array}$ & $\begin{array}{c}123 \pm 3 \\
(114-128)\end{array}$ & $\begin{array}{l}6 \pm 1 \\
(3-9)\end{array}$ & 7 & $\begin{array}{l}0.9 \pm 1.3 \\
(0.2-3.9)\end{array}$ & $\begin{array}{l}3 \pm 2 \\
(2-7)\end{array}$ \\
\hline I & 80 & 39 & $\begin{array}{c}50 \pm 7 \\
(40-80)\end{array}$ & $\begin{array}{c}758 \pm 192 \\
(456-1134)\end{array}$ & $\begin{array}{c}124 \pm 3 \\
(116-129)\end{array}$ & $\begin{array}{l}6 \pm 1 \\
(4-9)\end{array}$ & 7 & $\begin{array}{l}0.3 \pm 0.1 \\
(0.2-0.4)\end{array}$ & $\begin{array}{c}2 \pm 0.4 \\
(2-3)\end{array}$ \\
\hline $\mathrm{J}$ & 68 & 43 & $\begin{array}{c}50 \pm 7 \\
(40-70)\end{array}$ & $\begin{array}{l}629 \pm 131 \\
(347-907)\end{array}$ & $\begin{array}{c}119 \pm 3 \\
(111-123)\end{array}$ & $\begin{array}{l}6 \pm 1 \\
(3-9)\end{array}$ & 8 & $\begin{array}{l}0.8 \pm 0.8 \\
(0.4-2.7)\end{array}$ & $\begin{array}{l}3 \pm 2 \\
(2-9)\end{array}$ \\
\hline K & 67 & 15 & $\begin{array}{c}50 \pm 5 \\
(40-60)\end{array}$ & $\begin{array}{l}550 \pm 156 \\
(311-790)\end{array}$ & $\begin{array}{c}120 \pm 4 \\
(115-127)\end{array}$ & $\begin{array}{l}6 \pm 1 \\
(4-8)\end{array}$ & 3 & $\begin{array}{l}0.6 \pm 0.2 \\
(0.4-0.8)\end{array}$ & $\begin{array}{c}3 \pm 0.6 \\
(2-3)\end{array}$ \\
\hline $\mathrm{L}$ & 64 & 35 & $\begin{array}{l}60 \pm 10 \\
(40-70)\end{array}$ & $\begin{array}{c}776 \pm 151 \\
(474-1047)\end{array}$ & $\begin{array}{c}122 \pm 3 \\
(114-128)\end{array}$ & $\begin{array}{l}7 \pm 2 \\
(3-9)\end{array}$ & 3 & $\begin{array}{l}0.4 \pm 0.1 \\
(0.3-0.4)\end{array}$ & $2 \pm 0$ \\
\hline $\mathrm{M}$ & 59 & 14 & $\begin{array}{l}50 \pm 11 \\
(30-60)\end{array}$ & $\begin{array}{c}903 \pm 194 \\
(641-1384)\end{array}$ & $\begin{array}{c}117 \pm 3 \\
(113-122)\end{array}$ & $\begin{array}{c}7 \pm 2 \\
(4-12)\end{array}$ & 2 & $\begin{array}{c}1 \pm 1 \\
(0.3-1.9)\end{array}$ & $\begin{array}{l}6 \pm 5 \\
(2-9)\end{array}$ \\
\hline $\mathrm{N}$ & 56 & 6 & $\begin{array}{c}50 \pm 6 \\
(40-60)\end{array}$ & $\begin{array}{c}867 \pm 84 \\
(758-970)\end{array}$ & $\begin{array}{c}111 \pm 4 \\
(104-115)\end{array}$ & $\begin{array}{l}7 \pm 1 \\
(5-7)\end{array}$ & 0 & NA & NA \\
\hline $\mathrm{O}$ & 52 & 14 & $\begin{array}{l}50 \pm 15 \\
(30-80)\end{array}$ & $\begin{array}{c}812 \pm 68 \\
(444-1167)\end{array}$ & $\begin{array}{c}119 \pm 3 \\
(110-125)\end{array}$ & $\begin{array}{c}6 \pm 1 \\
(3-10)\end{array}$ & 0 & NA & NA \\
\hline $\mathrm{P}$ & 48 & 9 & $\begin{array}{c}40 \pm 7 \\
(40-60)\end{array}$ & $\begin{array}{c}851 \pm 54 \\
(766-970)\end{array}$ & $\begin{array}{c}115 \pm 3 \\
(109-120)\end{array}$ & $\begin{array}{l}6 \pm 1 \\
(4-8)\end{array}$ & 0 & NA & NA \\
\hline Q & 57 & 11 & $\begin{array}{l}50 \pm 12 \\
(30-70)\end{array}$ & $\begin{array}{c}800 \pm 72 \\
(639-884)\end{array}$ & $\begin{array}{c}120 \pm 2 \\
(117-124)\end{array}$ & $\begin{array}{l}6 \pm 1 \\
(5-8)\end{array}$ & 0 & NA & NA \\
\hline
\end{tabular}


Teeth possessing a tightening before sharp tips were also found on the lower pharyngeal jaw (Fig. 4D). Medial teeth were the largest and their size decreased from the centre to the periphery. At the anterior part, some lateral teeth of lower pharyngeal jaws were more elongated and directed laterally.

Ceratobranchials (CBR) 4 had teeth on their dorsal anterior half. These teeth were not evenly distributed, forming five triangular groups of 12-14 teeth (Fig. 4E). Smaller teeth were found at the tip of triangles, whereas longer teeth were found at the base, close to the elongated teeth of the lower pharyngeal jaw (Fig. 4F).

Teeth tips showed an orange colouration (Fig. 4G). Enamel of the most external and thin teeth in upper and lower pharyngeal jaws, and even in ceratobranchials 4, showed erosion (Fig. 4F).
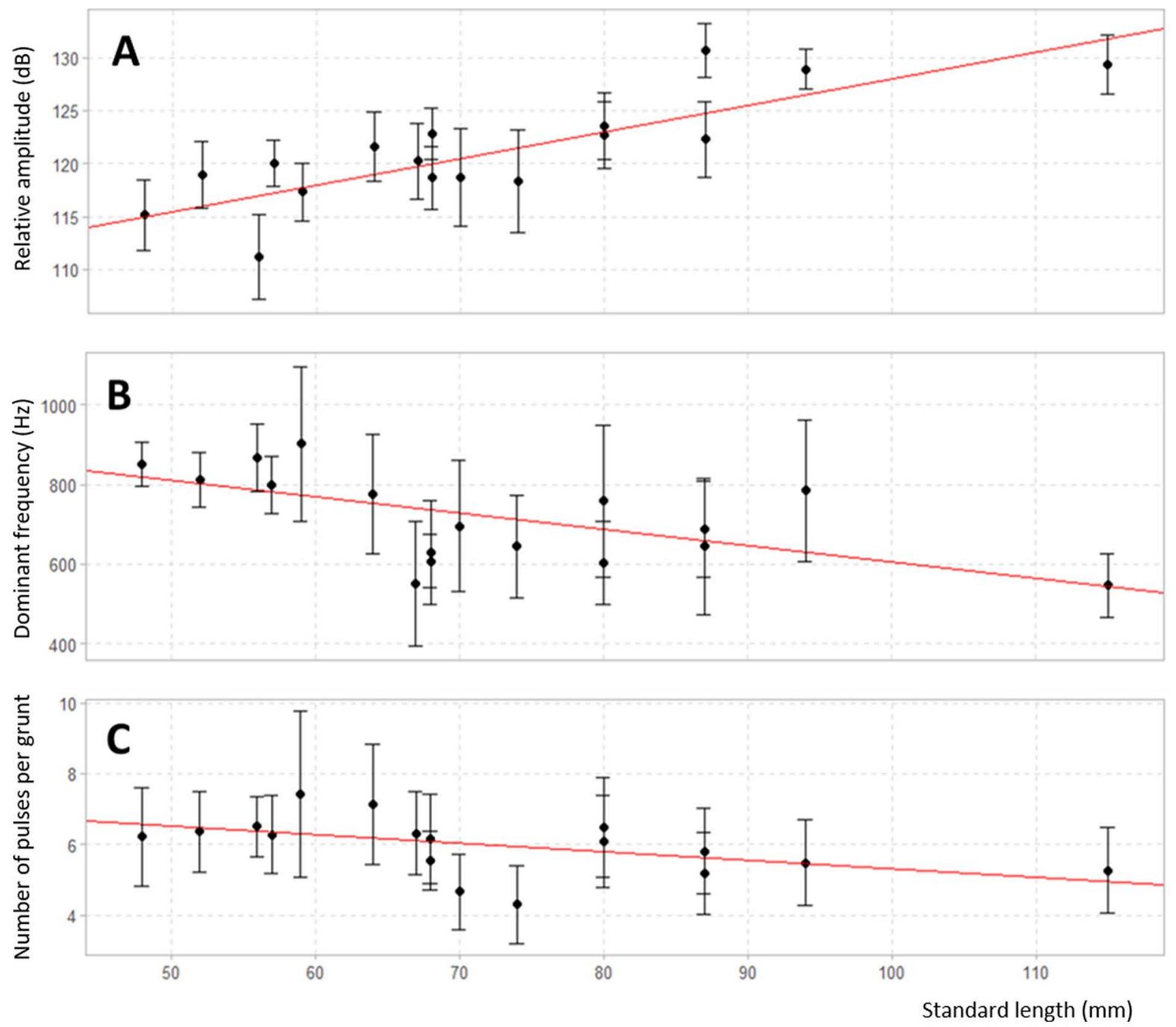

Fig. 3 - Relationship between acoustic features and standard length for sounds produced by Haemulon aurolineatum. A. Relative amplitude $(\mathrm{dB})$ and standard length $(\mathrm{mm}), \mathrm{Amp}=(0.24 \pm 0.04) *$ Standard length $+(103 \pm 3)$, p-value $<0.001$. B. Dominant frequency $(\mathrm{Hz})$ and standard length $(\mathrm{mm})$, $\mathrm{Fd}=(-4.11 \pm 1.41) *$ Standard length $+(1016 \pm 106), \mathrm{p}$-value $=0.01$. C. Number of pulses per grunt and standard length $(\mathrm{mm}), \mathrm{nbr}=(-0.02 \pm 0.01) *$ Standard length $+(7.7 \pm 0.8), \mathrm{p}$-value $=0.05$. 

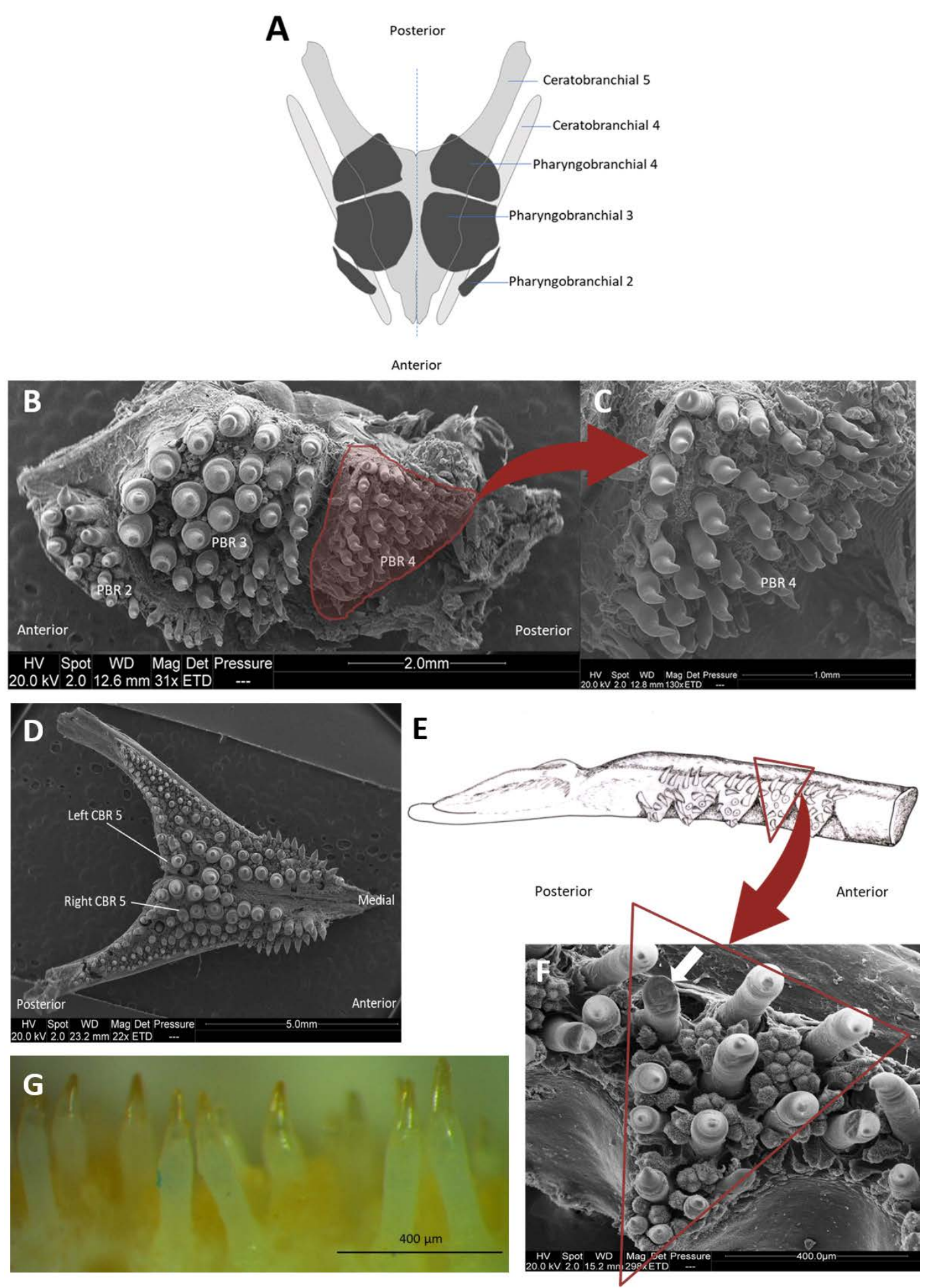

Fig. 4 - Morphology of pharyngeal jaws of Haemulon aurolineatum. A. Drawing of the dorsal view of pharyngeal jaws. B. Classical secondary electron imaging (SEM) of the ventral view of the upper pharyngeal jaw. C. Pharyngobranchial 4. D. Classical SEM of the dorsal view of lower pharyngeal jaw. E. Drawing of left ceratobranchials 4. F. Classical SEM of triangular group of teeth of left ceratobranchials 4, white arrow indicates traces of erosion. G. Binocular microscope observation of teeth of pharyngeal jaws showing an orange coloration. $\mathrm{PBR}=$ pharyngobranchial, $\mathrm{CBR}=$ ceratobranchial. 
MILLOT M. et al., Sound production and associated pharyngeal jaws in the tomtate grunt

Pharyngeal muscles were similar to pharyngeal muscles illustrated in H. flavolineatum (BERTUCCI et al. 2014) and in 9 different haemulid species (WAINWRIGHT 1989b). Observations of the inner mouth during sound production (in air) confirms movements were done at the level of the pharyngeal jaws during sound production.

\section{Discussion}

Stridulation sounds are often composed of a series of irregular transient pulses, containing a wide range of frequencies and great variation in temporal parameters (FINE \& PARMENTIER 2015; HAWKINS 1993; LADICH 1997). Similar to other vocal haemulids, the sounds of $H$. flavolineatum consist of rapidly produced grunts that show important variability in both pulse period and sound duration with broadband frequency ranging from 303 to $1384 \mathrm{~Hz}$. Sound features, movements at the level of pharyngeal jaws during sound production and common features in the branchial basket anatomy suggest a common morphological mechanism to produce sounds in these haemulids. Most sounds resulting from movements of pharyngeal teeth are thought to be by-products of feeding activities (PARMENTIER et al. 2013). In the present study, specimens did not feed and produced sounds, whether isolated or in series, when being handheld. The smallest specimens produced only isolated grunts. The production of grunts, whether single or in series, could suggest different meanings or motivations of the sound producer. Although the sex or sexual maturity of specimens were not determined, the range of the size of the 19 specimens probably encompassed both sexes. This means the ability to produce sounds is not related to sex or age.

A wide dominant frequency range (between 303 and $1384 \mathrm{~Hz}$ ) and a high variability of pulse period could be a characteristic of sounds produced by stridulation (DEMSKI et al.1973; FINE \& PARMENTIER 2015; TAVOLGA 1971). Three main kinds of stridulating sound-production mechanisms have been described in teleost species: friction of pectoral spine against the pectoral girdle in different catfish species (FINE et al. 1996; PARMENTIER et al. 2010b), articulation between two bones in the back of the head in seahorses (LIM et al. 2015), and rubbing of the pharyngeal teeth in haemulid grunts (BERTUCCI et al. 2014; BURKENROAD 1930) and gobies (TAKEMURA 1984). In teleosts, the lower pharyngeal jaws are only composed of ceratobranchials 5 (VANDEWALLE et al. 2000; WAINWRIGHT 2005). Ceratobranchials 4 are usually not part of lower pharyngeal jaws and they do not possess teeth that could help in food processing. However, fourth ceratobranchials commonly possess movable gill rakers, as it is the case for ceratobranchials 1, 2 and 3. In teleosts, these skeletal pieces are at least used to protect gills during water flow (VANDEWALLE et al. 2000). Nevertheless, the case of Haemulon species seems to be more complex. They do not possess movable gill rakers on the dorsal margin of fourth ceratobranchials, but rather teeth that are clearly implanted in triangular bony plates and that face teeth of the upper pharyngeal jaws. Moreover, the synchronous activities of pharyngeal muscles ventral to ceratobranchials 4 and 5 confirm that all these skeletal elements could act as a single unit (WAINWRIGHT 1989b). This characteristic is also found in the French grunt (H. flavolineatum), with both species possessing the same pharyngeal muscles. All these morphological and acoustic similarities suggest sounds are produced in the same way. Movements of pharyngeal jaws have been described for the French grunt through high-speed X-ray video recordings during sound production (BERTUCCI et al. 2014). These observations have shown that sounds were effectively the result of scratching the teeth of the upper and lower pharyngeal jaws. Moreover, erosion of teeth of the upper and lower pharyngeal jaws could result from a friction between these two pharyngeal units.

Although data from the literature do not allow deep comparisons, it seems that the same kind of sounds have been recorded in other haemulid species (BURKENROAD 1930; FISH \& MOWBRAY 1970; MouLton 1958), meaning they should also use the same kind of mechanism. Haemulon 
plumieri, $H$. flavolineatum and $H$. aurolineatum, for example, have common anatomy at the level of ceratobranchials 4. Although unusual within teleosts, the organisation of teeth in triangular patches on the ceratobranchials 4 is not referred to as a synapomorphy in the haemulid literature (JOHNSON 1981). However, we hypothesise that this feature coincides with the ability to make sounds. This could be true for all 23 valid Haemulon species (www.fishbase.se 2019). As sounds were also recorded (but not described) in haemulid specimens from the Anisotremus, Conodon, Pomadasys and Orthopristis species (FISH \& MOWBRAY 1970), we expect that the same kind of anatomy can be found in these species. However, such sound features and anatomy remain to be studied. Moreover, all these genera belong to the sub-family Haemulinae, meaning additional data are required to understand the acoustic abilities of the second subfamily, the Plectorhinchinae.

In $H$. aurolineatum, there was a negative relation between dominant frequency and size of the sound producer. Decreasing dominant sound frequencies with increasing body size is a general phenomenon in animals (HENGLMÜLLER \& LADICH 1999). This negative relation was found in several teleost species (AMORIM et al. 2003; BERTUCCI et al. 2012; DE JONG et al. 2007; Myrberg \& LUGLI 2006; PRUZSINSZKY \& LADICH 1998). This supports the notion that sounds could provide information on the size of the sound producer (COLLEYE et al. 2009; LOBEL \& MANN 1995). In addition, one study revealed that this relationship could provide information about the morphological mechanism responsible for sound production (PARMENTIER \& FINE 2016). In species producing sounds with fast-contracting muscles, the relationship between the dominant frequency and fish size is weak, since the slopes are between 1 and $10^{\circ}$. When the soundproducing mechanism is not based on direct muscle contractions, slopes were steeper, between 60 and $97^{\circ}$ (PARMENTIER \& FINE 2016). In the tomtate grunt, the steep slope $\left(85^{\circ}\right)$ suggests that the sound production mechanism is not based on fast-contracting muscles, reinforcing our hypothesis on the stridulatory mechanism. A positive relation was also found between amplitude and fish size: large specimens produce louder sounds than small specimens. This relationship was found in different studies (BOYLE \& TRICAS 2011; CONNAUGHTON et al. 2000; KNIGHT \& LADICH 2014; LINDSTRÖM \& LUGLI 2000; PARMENTIER et al. 2017b; TAKEMURA 1984) but there is no satisfactory explanation for this positive relation to date. Relationships were found between three acoustic features (dominant frequency, amplitude, and number of pulses per grunt) and size, which could allow a precise estimation of the size of a specimen just by listening to sounds.

\section{Conclusion}

Current studies in marine ecology are trying to develop monitoring of underwater areas based on the identification of species-specific sounds. For this, describing the sounds and understanding in which contexts they are produced by closely related species appears particularly necessary. This study showed that Haemulon aurolineatum is able to produce sounds using a stridulatory mechanism. This could be related to a family feature since, unlike other teleost species, ceratobranchials 4 appear to be part of lower pharyngeal jaws. This feature could be related to the ability to produce loud sounds with teeth of the branchial basket. Additional studies in other Haemulidae species are required to further describe the ceratobranchials 4 morphology.

\section{Acknowledgements}

This work was supported by several grants: Fondation de France (2019-08602), LabEx CORAIL (project 2018 Emul), ANR-19-CE34-0006-Manini, Fonds de la Recherche scientifique - FNRS, Grant/Award Number T.0192.20 - PDR. 
MILLOT M. et al., Sound production and associated pharyngeal jaws in the tomtate grunt

\section{References}

Amorim M.C.P., Conti C., Modesto T., Gonçales A. \& FonseCa P.J. (2015). Agonistic sounds signal male quality in the Lusitanian toadfish. Physiology \& Behavior 149: 192-198. https://doi.org/10.1016/j.physbeh.2015.06.002

AMORIM, M.C.P., FonseCA, P.J. \& Almada V.C. (2003). Sound production during courtship and spawning of Oreochromis mossambicus: male-female and male-male interactions. Journal of Fish Biology 62: 658-672. https://doi.org/10.1046/j.1095-8649.2003.00054.x

AMORIM M.C.P. \& HAWKINS A.D. (2005). Ontogeny of acoustic and feeding behaviour in the grey gurnard, Eutrigla gurnardus. Ethology 111: 255-269. https://doi.org/10.1111/j.1439-0310.2004.01061.x

Bertucci F., AtTia J., Beauchaud M. \& Mathevon N. (2012). Sounds produced by the cichlid fish Metriaclima zebra allow reliable estimation of size and provide information on individual identity. Journal of Fish Biology 80: 752-766. https://doi.org/10.1111/j.1095-8649.2012.03222.x

Bertucci F., Ruppé L., VAn Wassenbergh S., Compère P. \& PARMentier E. (2014). New insights into the role of the pharyngeal jaw apparatus in the sound-producing mechanism of Haemulon flavolineatum (Haemulidae). Journal of Experimental Biology 217: 3862-3869. Available from https://jeb.biologists.org/content/217/21/3862 [accessed 12 February 2021].

BOYLE K.S. \& TRICAS T.C. (2011). Sound production in the longnose butterflyfishes (genus Forcipiger): cranial kinematics, muscle activity and honest signals. Journal of Experimental Biology 214: 38293842. Available from https://jeb.biologists.org/content/214/22/3829 [accessed 12 February 2021].

BurKenroAd M.D. (1930). Sound production in the Haemulidae. Copeia 1930: 17-18.

Colleye O., Frédérich B., Vandewalle P., Casadevall M. \& Parmentier E. (2009). Agonistic sounds in the skunk clownfish Amphiprion akallopisos: size related variation in acoustic features. Journal of Fish Biology 75: 908-916. https://doi.org/10.1111/j.1095-8649.2009.02316.x

Colleye O., Vandewalle P., LanterbecQ D., Lecchini D. \& Parmentier E. (2011). Interspecific variation of calls in clownfishes: degree of similarity in closely related species. BMC evolutionary biology 11: 365. https://doi.org/10.1186/1471-2148-11-365

COLleye O \& PARMENTIER E (2012). Overview on the diversity of sounds produced by clownfishes (Pomacentridae): importance of acoustic signals in their peculiar way of life. PLoS ONE 7 (11): e49179. https://doi.org/10.1371/journal.pone.0049179

Connaughton M.A., TAYlor M.H. \& Fine M.L. (2000). Effects of fish size and temperature on weakfish disturbance calls: implications for the mechanism of sound generation. Journal of Experimental Biology 203: 1503-1512.

CUMmings W.C., Brahy B.D. \& SPIRES J.Y. (1966). Sound production, schooling, and feeding habits of the margate, Haemulon album Cuvier, off North Bimini, Bahamas. Bulletin of Marine Science 16: 626-640.

DARCY, G.H. 1983. Synopsis of biological data on the grunts Haemulon aurolineatum and H. plumieri (Pisces: Haemulidae). FAO Fisheries Synopsis 133.

De Jong K., Bouton N. \& SLABBeKOORN H. (2007). Azorean rock-pool blennies produce size-dependent calls in a courtship context. Animal Behaviour 74: 1285-1292. https://doi.org/10.1016/j.anbehav.2007.02.023

DEMSKi L.S., GERALD J.W. \& POPPER A.N. (1973). Central and peripheral mechanisms of teleost sound production. American Zoologist 13: 1141-1167. 
Fine M.L., McElroy D., Rafi J., King C.B., Loesser K.E. \& Newton S. (1996). Lateralization of pectoral stridulation sound production in the channel catfish. Physiology \& Behavior 60: 753-757. https://doi.org/10.1016/0031-9384(96)00092-3

FINE M.L. \& PARMENTIER E. (2015). Mechanisms of fish sound production. In: LADICH F. (ed.) Sound Communication in Fishes: 77-126. Springer, Wien.

FISH M.P. \& MowBraY W.H. (1970). Sounds of Western North Atlantic Fishes: A Reference File of Biological Underwater Sounds. The Johns Hopkins University Press, Baltimore.

FISHBASE. (2019). Scientific names where genus equals haemulon. Available from www.fishbase.org [accessed July 2020].

GERALD J.W. (1971). Sound production during courtship in six species of sunfish (Centrarchidae). Evolution 25: 75-87. Available from https://www.jstor.org/stable/2406500 [accessed 12 February 2021].

Gould S.J. \& VRBA E.S. (1982). Exaptation: a missing term in the science of form. Paleobiology 8: 4-15. Available from https://www.jstor.org/stable/2400563 [accessed 12 February 2021].

HAWKINS A.D. \& RASMUSSEN K.J. (1978). The calls of gadoid fish. Journal of the Marine Biological Association of the United Kingdom 58: 891-911. https://doi.org/10.1017/S0025315400056848

HENGLMÜLLER S.M. \& LADICH F. (1999). Development of agonistic behaviour and vocalization in croaking gouramis. Journal of Fish Biology 54: 380-395. https://doi.org/10.1111/j.1095-8649.1999.tb00837.x

JOHNSON G.D. (1981). The limits and relationships of the Lutjanidae and associated families. In: Cox C.S., Vincent E.S., Flem-Inger A. \& RosenBlatt R.H. (eds) Bulletin of the Scripps Institution of Oceanography: 1-112. University of California Press, Berkeley.

KNIGHT L. \& LADich F. (2014). Distress sounds of thorny catfishes emitted underwater and in air: characteristics and potential significance. Journal of Experimental Biology 217: 4068-4078. https://doi.org/10.1242/jeb.110957

Lim A.C.O., Chong V.C., Chew W.X., Muniandy S.V., Wong C.S. \& Ong Z.C. (2015). Sound production in the tiger-tail seahorse Hippocampus comes: insights into the sound producing mechanisms. The Journal of the Acoustical Society of America 138: 404-412. https://doi.org/10.1121/1.4923153

LINDSTRÖM K. \& LUGLI M. (2000). A quantitative analysis of the courtship acoustic behaviour and sound patterning in male sand goby, Pomatoschistus minutus. Environmental Biology of Fishes 58: 411424. https://doi.org/10.1023/A:1007695526177

LOBEL P.S. (1992). Sounds produced by spawning fishes. Environmental Biology of Fishes 33: 351-358. https://doi.org/10.1007/BF00010947

LOBEL P.S. \& MANN D.A. (1995). Spawning sounds of the damselfish, Dascyllus albisella (Pomacentridae), and relationship to male size. Bioacoustics 6: 187-198. https://doi.org/10.1080/09524622.1995.9753289

MalaVASi S., Collatuzzo S. \& TORRICElli P. (2008). Interspecific variation of acoustic signals in Mediterranean gobies (Perciformes, Gobiidae): comparative analysis and evolutionary outlook. Biological Journal of the Linnean Society 93: 763-778. https://doi.org/10.1111/j.1095-8312.2008.00947.x

MANOOCH C.S. \& BARANS C.A. (1982). Distribution, abundance, and age and growth of the tomtate, Haemulon aurolineatum, along the southeastern United States coast. Fishery Bulletin 80: 1-20.

Moulton J.M. (1958). The acoustical behavior of some fishes in the Bimini area. The Biological Bulletin 114: 357-374. https://doi.org/10.2307/1538991 
MILLOT M. et al., Sound production and associated pharyngeal jaws in the tomtate grunt

MYrberg A.A. \& Lugli M. (2006). Reproductive behavior and acoustical interactions. In: LADICH F., COLlin S.P., MOLleR P. \& KAPOOR B.G. (eds) Communication in Fishes: 149-176. Science Publishers Inc., Enfield.

Myrberg JR A.A., HA S.J. \& ShAmblotT M.J. (1993). The sounds of bicolor damselfish (Pomacentrus partitus): predictors of body size and a spectral basis for individual recognition and assessment. The Journal of the Acoustical Society of America 94: 3067-3070. https://doi.org/10.1121/1.407267

PARMentier E., Fabri G., KAatz I., Decloux N., Planes S. \& VANDEWAlle P. (2010a). Functional study of the pectoral spine stridulation mechanism in different mochokid catfishes. Journal of Experimental Biology 213: 1107-1114. https://doi.org/10.1242/jeb.039461

Parmentier E., Kéver L., Casadevall M. \& LeCchini D. (2010b). Diversity and complexity in the acoustic behaviour of Dacyllus flavicaudus (Pomacentridae). Marine Biology 157: 2317-2327. https://doi.org/10.1007/s00227-010-1498-1

Parmentier E., Kéver L., Boyle K., Corbisier, Y.-E., SAWElew L. \& Malavasi S. (2013). Sound production mechanism in Gobius paganellus (Gobiidae). Journal of Experimental Biology 216: 31893199. https://doi.org/10.1242/jeb.087205

Parmentier E., Tock J., Falguière J.-C. \& Beauchaud M. (2014). Sound production in Sciaenops ocellatus: preliminary study for the development of acoustic cues in aquaculture. Aquaculture 432: 204211. https://doi.org/10.1016/j.aquaculture.2014.05.017

PARMENTIER E. \& Fine M.L. (2016). Fish sound production: insights. In: SUTHERS R.A., TeCuMSEH F., FAY R.R. \& POPPER A.N. (eds) Vertebrate Sound Production and Acoustic Communication: 19-46. Springer, Handbook of Auditory Research vol. 53. https://doi.org/10.1007/978-3-319-27721-9_2

PARMENTIER E., Diogo R. \& Fine M.L. (2017a). Multiple exaptations leading to fish sound production. Fish and Fisheries 18: 958-966. https://doi.org/10.1111/faf.12217

Parmentier E., Raick X., Lecchini D., Boyle K., Van Wassenbergh., Bertucci F. \& Kéver L. (2017b). Unusual sound production mechanism in the triggerfish Rhinecanthus aculeatus (Balistidae). Journal of Experimental Biology 220: 186-193. https://doi.org/10.1242/jeb.157263

Pedroso S.S., BARber I., Svensson O., FonseCa P.J. \& AMOrim M.C.P. (2013). Courtship sounds advertise species identity and male quality in sympatric Pomatoschistus spp. gobies. PLoS One 8: e64620. https://doi.org/10.1371/journal.pone.0064620

Picciulin M., Sebastianutto L., Costantini M., Rocca M. \& Ferrero E.A. (2006). Aggressive territorial ethogram of the red-mouthed goby, Gobius cruentatus (Gmelin, 1789). Electronic Journal of Ichthyology 2: 8419.

PRUZSINSZKY I. \& LADICH F. (1998). Sound production and reproductive behaviour of the armoured catfish Corydoras paleatus (Callichthyidae). Environmental Biology of Fishes 53: 183-191. https://doi.org/10.1023/A:1007413108550

RCORE TEAm (2018). R Development Core Team. R: A Language and Environment for Statistical Computing. R Foundation for Statistical Computing, Vienna.

SCHNEIDER H. (1967). Morphology and physiology of sound-producing mechanisms in teleost fishes. Marine Bio-Acoustics 2: 135-158.

TAKEMURA A. (1984). Acoustical behavior of the freshwater goby Odontobutis obscura. Bulletin of the Japanese Society of Scientific Fisheries 50: 561-564.

TAVOLGa W.N. (1971). Sound production and detection. Fish physiology. In: HOAR W.S. \& RANDALL D.J. (eds) Fish Physiology, vol. 5: 135-205. Academic press, New York. 
TAVOLGA W.N. \& WODINSKY J. (1965). Auditory capacities in fishes: threshold variability in the blue-striped grunt, Haemulon sciurus. Animal Behaviour 13: 301-311. https://doi.org/10.1016/0003-3472(65)90050-3

Tellechea J.S., Martinez C., Fine M.L. \& Norbis W. (2010). Sound production in the whitemouth croaker and relationship between fish size and disturbance call characteristics. Environmental Biology of Fishes 89: 163-172. https://doi.org/10.1007/s10641-010-9709-7

Vandewalle P., Parmentier E. \& Chardon M. (2000). The branchial basket in Teleost feeding. Cybium 24: 319-342.

WAINWRIGHT P.C. (1989a). Functional morphology of the pharyngeal jaw apparatus in perciform fishes: an experimental analysis of the Haemulidae. Journal of Morphology 200: 231-245. https://doi.org/10.1002/jmor.1052000302

WAINWRIGHT P.C. (1989b). Prey processing in haemulid fishes: patterns of variation in pharyngeal jaw muscle activity. Journal of Experimental Biology 141: 359-375.

WAINWRIGHT P.C. (2005). Functional morphology of the pharyngeal jaw apparatus. Fish physiology 23: 77-101. https://doi.org/10.1016/S1546-5098(05)23003-0

Received: 6 September 2020

Accepted: 27 January 2021

Published on: 25 February 2021

Branch editor: Dominique Adriaens 